\section{Managing Ebola from rural to urban slum settings: experiences from Uganda.}

Sam I Okware ${ }^{1}$, Francis Omaswa 2 , Ambrose Talisuna $a^{3}$, Jacinto Amandua $a^{4}$, Jackson Amone ${ }^{4}$, Paul Onek ${ }^{5}$, Alex Opio $^{6}$, Joseph Wamala ${ }^{7}$, Julius Lubwama ${ }^{8}$, Lukwago Luswa ${ }^{7}$, Paul Kagwa9 ${ }^{9}$, Thorkild Tylleskar ${ }^{10}$

1. Uganda National Health Research Organisation, Entebbe, Uganda.

2. African Centre for Health and Social Transformation, Kampala.

3. Public Health and Health Systems Research, University of Oxford- KEMRI

Welcome Trust Program, Nairobi, Kenya

4. Curative Services, Ministry of Health,, Kampala, Uganda

5. District Director Health Services, Gulu district, Uganda

6. Department disease Control, Ministry of Health, Kampala, Uganda

7. Division of Epidemiology and Disease Control, Ministry of Health, Uganda

8. Uganda Virus Institute, Entebbe, Uganda

9. Health Education Division, Ministry of Health, Uganda

10. Centre for International Health, University of Bergen, Norway

\section{Abstract}

Background: Five outbreaks of ebola occurred in Uganda between 2000-2012. The outbreaks were quickly contained in rural areas. However, the Gulu outbreak in 2000 was the largest and complex due to insurgency. It invaded Gulu municipality and the slum- like camps of the internally displaced persons (IDPs). The Bundigugyo district outbreak followed but wa detected late as a new virus. The subsequent outbreaks in the districts of Luwero district $(2011,2012)$ and Kibaale (2012) were limited to rural areas.

Methods: Detailed records of the outbreak presentation, cases, and outcomes were reviewed and analyzed. Each outbreak was described and the outcomes examined for the different scenarios

Results: Early detection and action provided the best outcomes and results. The ideal scenario occurred in the Luwero outbreak during which only a single case was observed. Rural outbreaks were easier to contain. The community imposed quarantine prevented the spread of ebola following introduction into Masindi district. The outbreak was confined to the extended family of the index case and only one case developed in the general population. However, the outbreak invasion of the town slum areas escalated the spread of infection in Gulu municipality. Community mobilization and leadership was vital in supporting early case detection and isolations well as contact tracing and public education.

Conclusion: Palliative care improved survival. Focusing on treatment and not just quarantine should be emphasized as it also enhanced public trust and health seeking behavior.

Early detection and action provided the best scenario for outbreak containment. Community mobilization and leadership was vital in supporting outbreak control. International collaboration was essential in supporting and augmenting the national was vitalin

Keywords: Ebola,Ugand

\section{DOI: http://dx.doi.org/10.4314/ahs.v15i1.45}

\section{Introduction}

Ebola virus disease (EVD) is a highly fatal emerging infection. It is an acute infectious febrile illness with no known cure. In 1976, the first outbreak occurred

\section{Corresponding author:}

Okware S.I

Uganda National Health Research

Organisation, Entebbe.

Email okwares@gmail.com es (dead or alive). Contact with killed bats or non-human primates is also linked to transmission. The liver spleen, thymus, and lymph nodes and macrophage rich near a river called Ebola, in the Democratic Republic of go $^{3-6}$ and Gabon 7 and about 2000 cases were reported in the 25 outbreaks. Until 2013, the Uganda outbreak was the biggest and most complex. Some 425 cases and 224 deaths occurred ${ }^{1,8}$ including 31 health care workers. Five distinct species of Ebola have been identified but only 3 have caused disease outbreaks in humans ${ }^{9,10}$. The lymphoid tissue, are targets for the Filoviruses. Liver the second ebola outbreak in Uganda which occurred damage leads to decreased production of clotting fac- in Bundibugyo district in 2007 laboratory confirmation tors and impairment of coagulation. The adrenal gland was carried out by CDC Atlanta. The two Luwero outmaintains blood pressure homeostasis. Its damage leads breaks in $2011^{12}$ and $2012^{13}$ together with the Kibaale to reduced production of steroids, sodium loss and hy- outbreak of 2012 were all confirmed by the Uganda povolaemia ${ }^{11}$. In this paper we report our experience Virus Research Institute.

with the Uganda ebola epidemics and discuss them in the context of the current ebola outbreak in West Africa.

\section{Methods:}

\section{Results:}

Figure 1 Ebola affected districts, Uganda, 2000-2012 The ebola outbreak of 2000 occurred in Gulu district ( Fig 1) in northern Uganda. Masindi and Mbarara During the Ebola outbreaks in Uganda we kept detailed districts were also affected with imported cases from records of the cases, presentation outcome. Laboratory Gulu. This was the first such outbreak in the country. confirmation was in South Africa, USA and Uganda. Insecurity due to insurgency from LRA rebels made The cause of the Gulu epidemic of 2000 was con- the rural villages inaccessible. Some 1.3 million interfirmed by the South Africa Institute of Virology. In nally displaced persons(IDPs) were leaving in slum like camps $^{14,15}$.

\section{Fig 1 Map of Uganda showing ebola affected districts, 2000-2012}

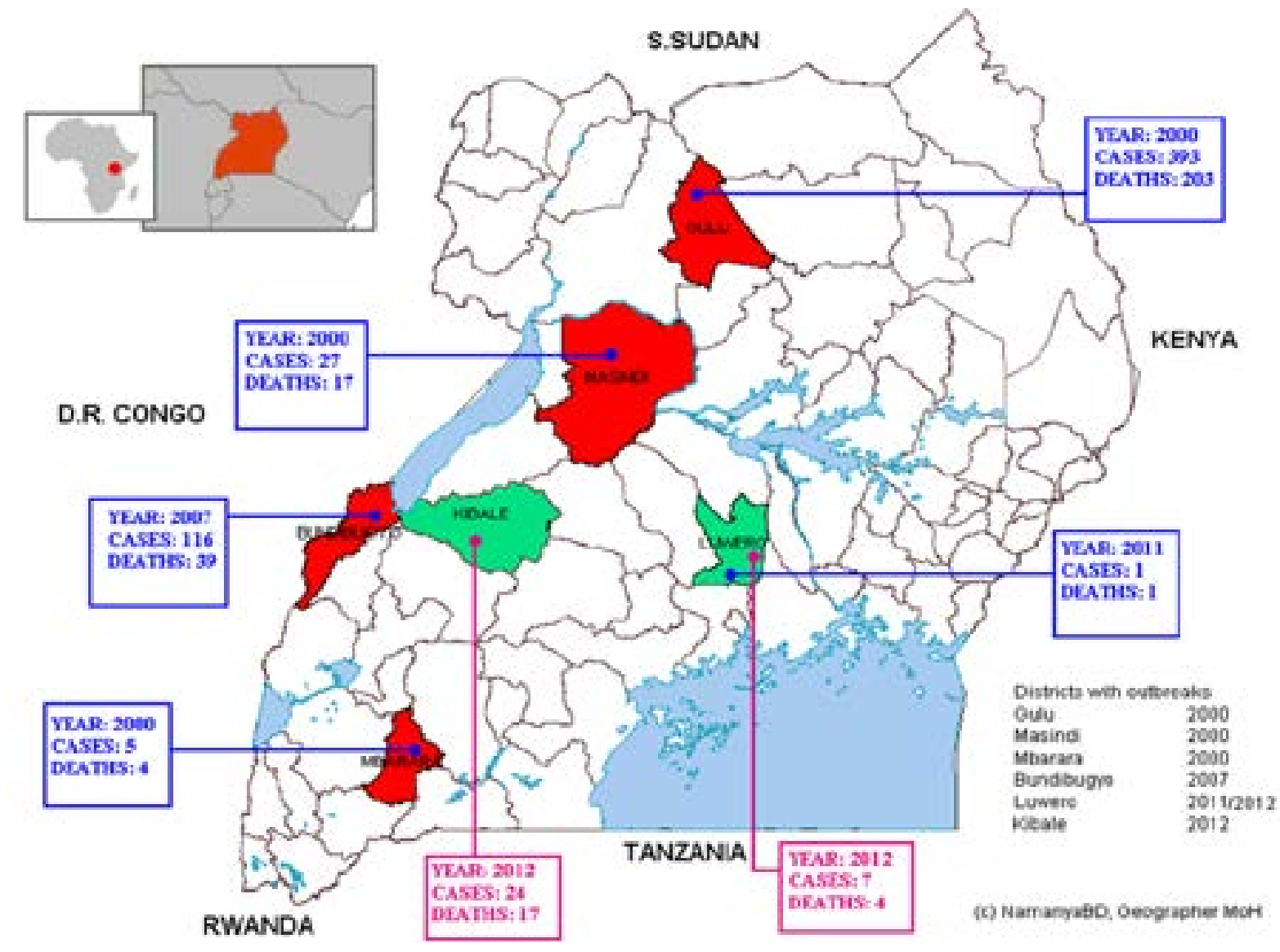

The camps were organised around trading centres or schools.

slums (Fig 2). Infrastructure had collapsed including schools and roads. The health care delivery system had deteriorated severely. There was an acute shortage of Each camp had between 1000 and 10,000 inhabitants staff due to lack of motivation to go to insurgency living in temporary huts with minimal sanitation and areas. Traditional beliefs explained the deaths within overcrowded. The camps were low grade towns and the context of witchcraft. The clustering of deaths by 
Figure 2: Camps of 1.3 million internally displaced persons (IDP), Gulu, Uganda,2000

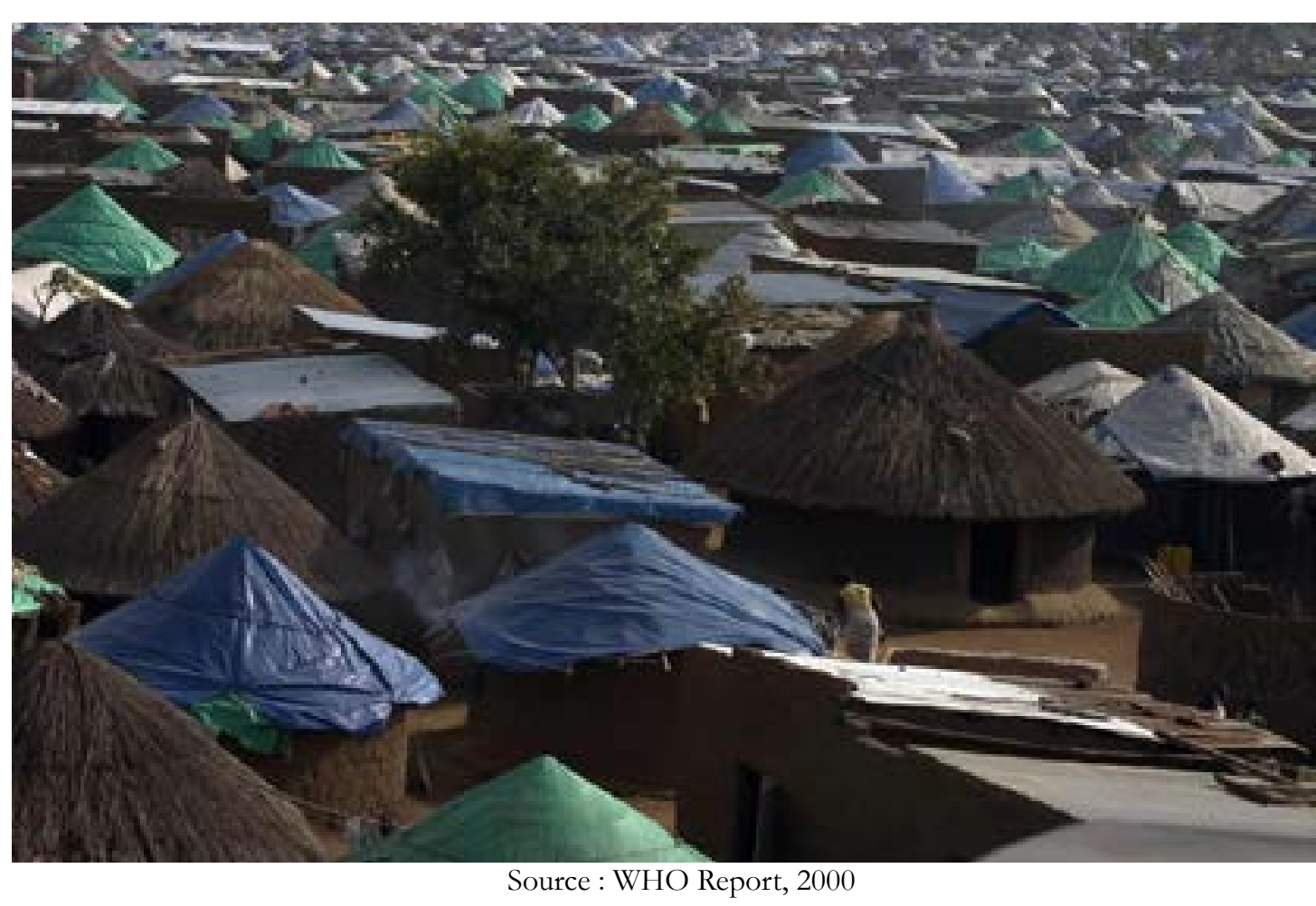

family lent support to this idea and fomented rumours, which the local media often capitalised on.

be followed a few days later by more nurses and patients. On the 14th October2000, the Su The epidemic started in a rural village around August Virology as the cause of the epidemic. Health worker $2000^{1,8}$. A husband and wife died followed by mem- panicked and fled leaving patients, most of who died in bers of the immediate households. It is after commu- the first weeks of the outbreak. Some IDP camp dwellnity members started dying that medical assistance was ers commuted to Gulu town at night to avoid abduction sought. Six weeks later the first cases were admitted to by the rebels (Fig 3). They also feared ebola in rural arLacor hospital. Three student nurses died that week to eas. Unfortunately they brought ebola with them to the

Fig 3: Internally displaced persons (IDP), Gulu municipality, 2000 Internally displaced people in Gulu Municipality

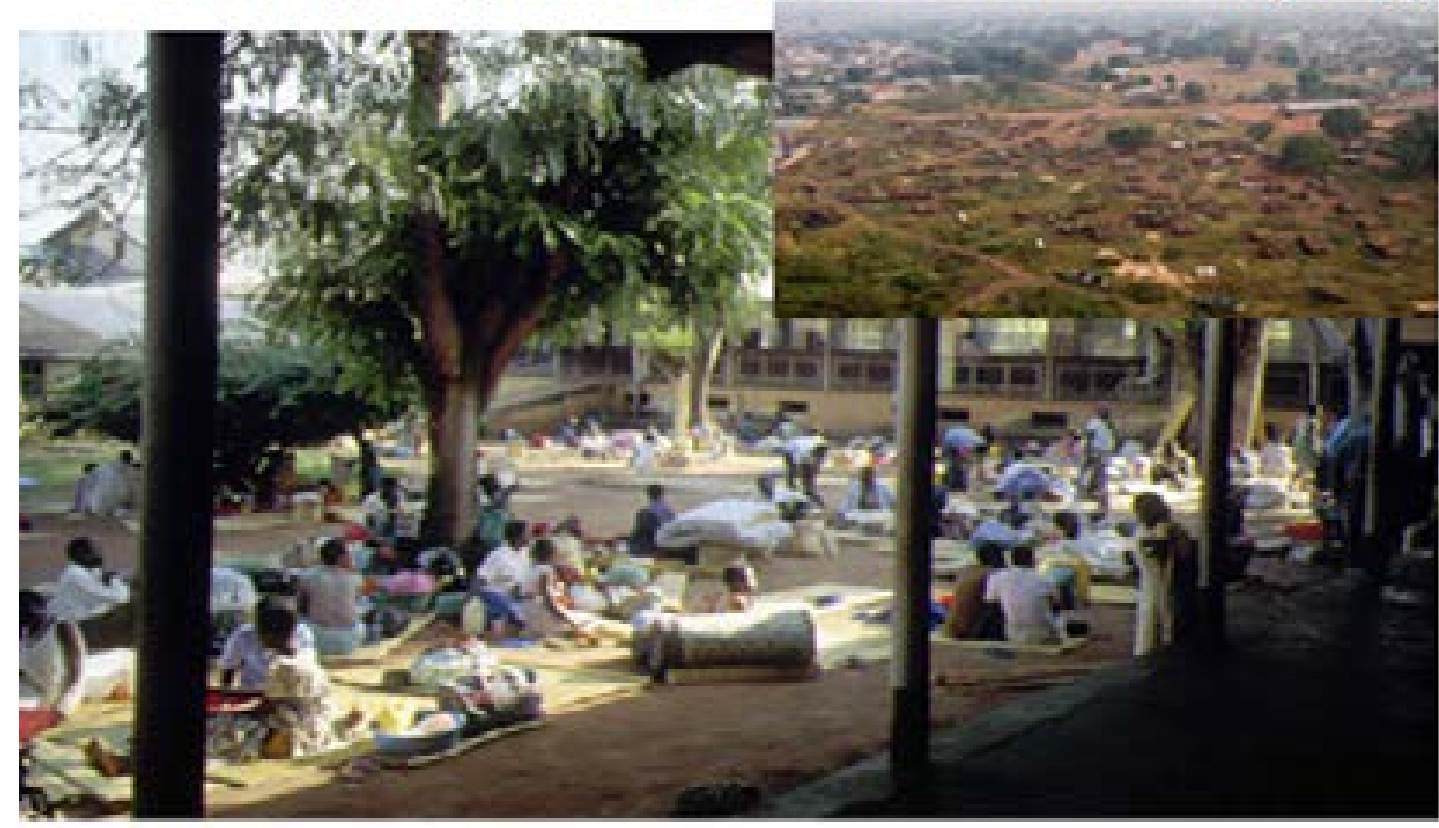

African Health Sciences Vol 15 Issue 1, March 2015 slum areas of Gulu Municipality. The urban invasion of ebola led to even more panic and scare. Cases escalated in the municipality.

Four more ebola outbreaks in the districts of Bundibugyo[2] (2007), Luwero (2011), Kibaale (2012) and Luwero in 2012 (Figure 1) have occurred. These outbreaks were basically rural and were ably contained.

The national response

The national response was comprehensive and multisectoral. His Excellency, the President mobilised the

Fig. 4: Surveillance flow chart for community cases detection and isolation

\section{Surveillance flow chart}

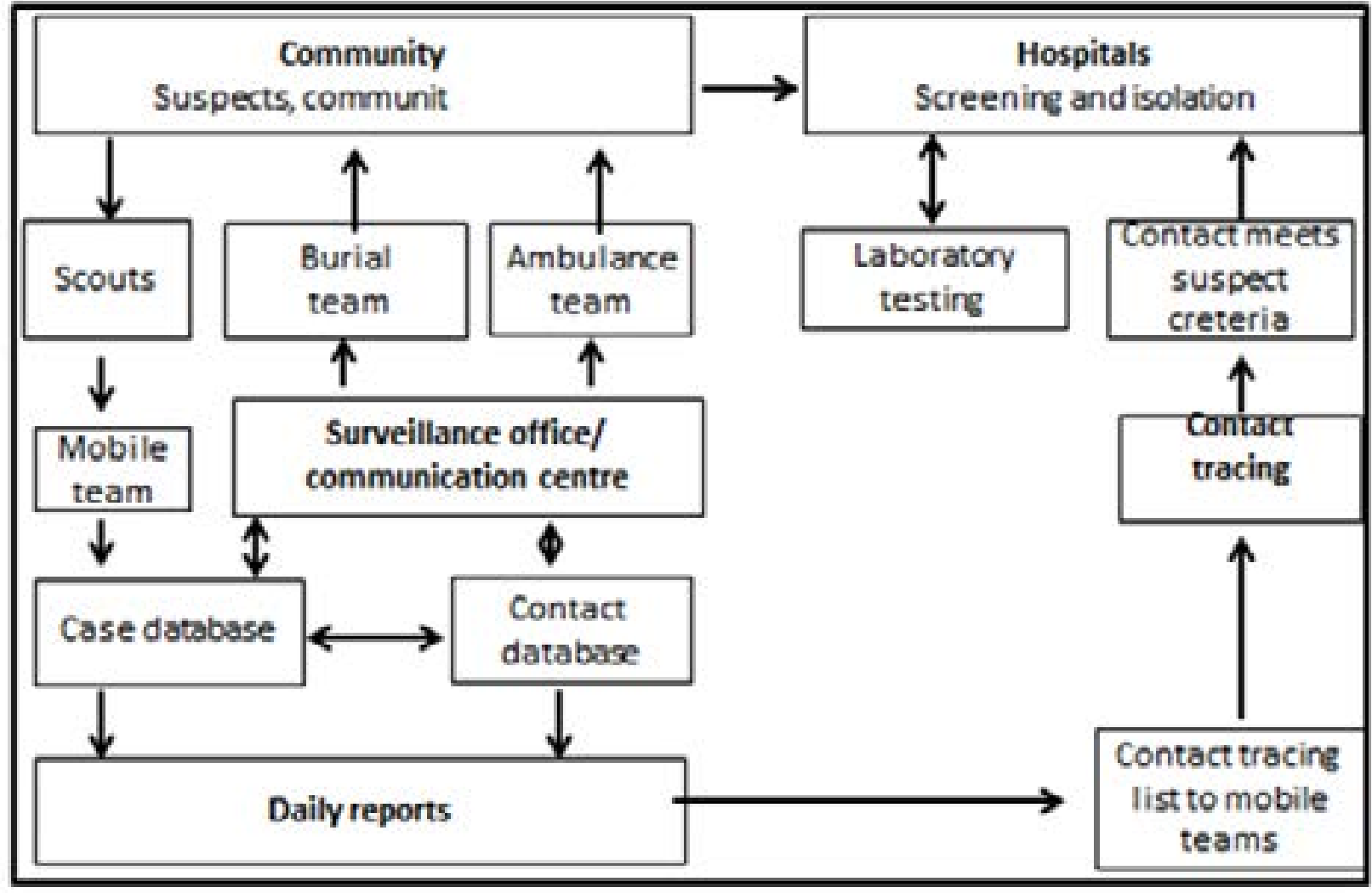

team members and the district coordinating and sur- force and surveillance office. They were actually hired veillance ${ }^{8}$. The entire response was coordinated by the for the period the outbreak lasted. Incentives were paid district task force and surveillance centre (Figure 4).

A special mobilisation team was required for the IDP camps, most of who were at great risk in view of the overcrowding and insanitary slum like environment. Camp leaders of blocks of 100 families were recruited, trained to undertake active case search of suspected cases. A village scout (secretary) supported the team with record keeping and liaison with the district tas to those for each ebola case reported and revalidated. A truce was negotiated between the community and the rebel leaders to allow free access to their area of operation. All the stakeholders including the rebels, security personnel and task force members were part of the 160 committed individuals that patrolled the camps and organised containment activities including burials and the ambulance service ${ }^{8}$. Soft power and negotiation and understanding were tools used with community in- 
Fig. 5 Cases fatality rate of confirmed cases by week, 18th September- 18th December 2000, Gulu

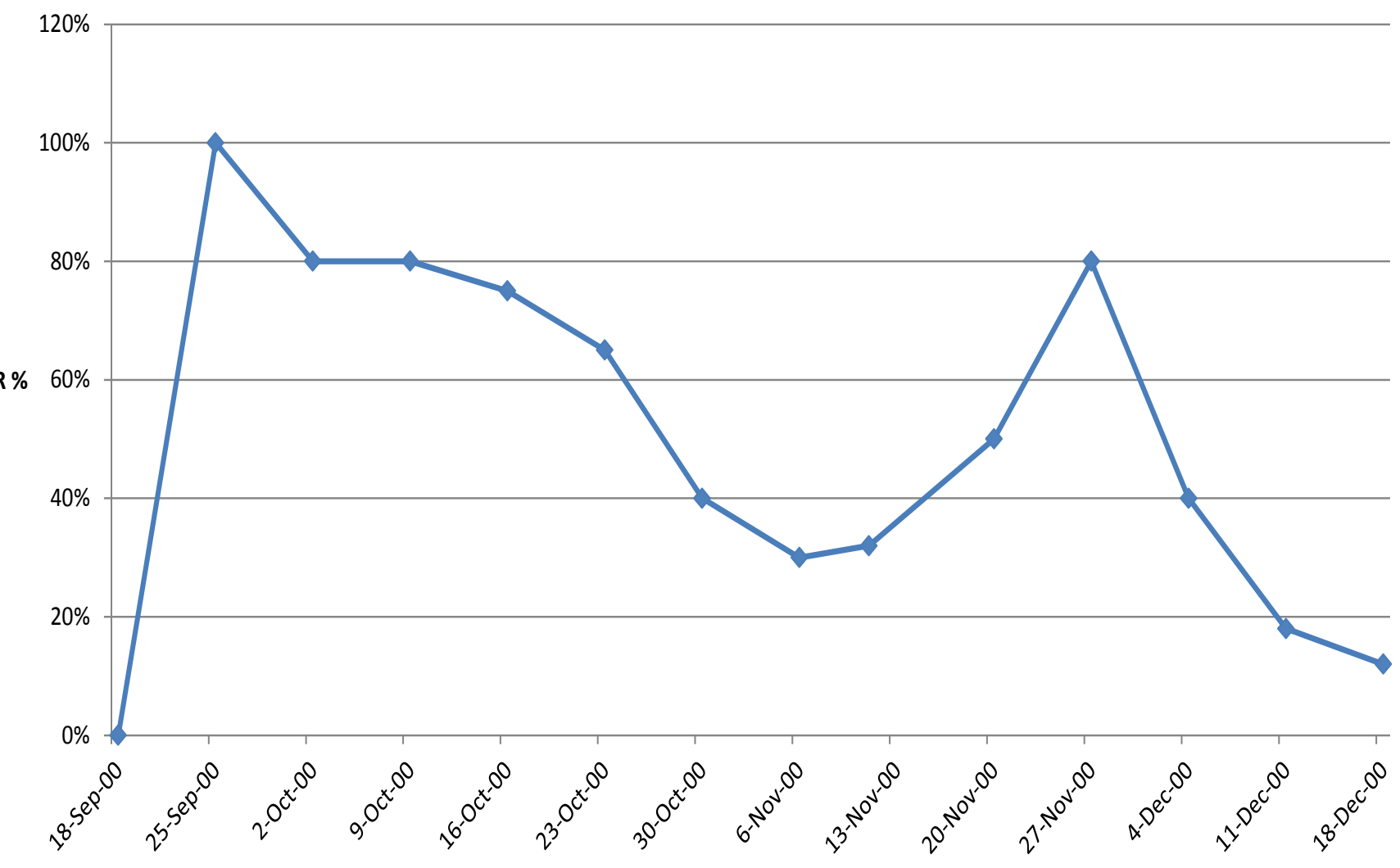

volvement. Isolation and palliative care was provided at announced in the evening of each day. This ensured Lacor and Gulu hospitals. Case fatality improved to less transparency and ably managed rumours. This outbreak than half towards the end of the outbreak (Fig 5)._u which stared in a rural area invaded Gulu municipality A mobile team or a trained burial team would be des- slums with devastating consequences. Some 393 cases patched immediately on request. The scout worked in Gulu district alone occurred. The most affected areas in liaison with the other levels and stakeholders. A were in the municipality (Table 1 ).The attack rates for single updated and jointly owned situation report was the municipality from slum areas was the highest $(15$

\section{Table 1: Cumulative ebola cases by most affected parish, Gulu municipality, Uganda, 2000}

Table 1: Cumulative ebola cases by most affected parish, Gulu municipality, Uganda, 2000
\begin{tabular}{|l|l|l|l|}
\hline Parish & Sub county & County & No. of cases* \\
\hline Kasubi & Bardege & Gulu Municipality & 40 \\
\hline Kirombe & Layibi & Gulu Municipality & 36 \\
\hline Atibaar & Bungatira & Aswa & 31 \\
\hline Bardege & Bardege & Municipality & 19 \\
\hline Kanyonga & Bardege & Municipality & 18 \\
\hline Techo & Layibi & Municipality & 17 \\
\hline Ariaga & Laroo & Municipality & 17 \\
\hline Pageya & Koro & Omoro & 16 \\
\hline Patudat & Layibi & Municipality & 15 \\
\hline Vanguara & Pece & Municipality & 13 \\
\hline Pabbo Kal & Pabbo & Kilak & 13 \\
\hline
\end{tabular}

*Population data at sub county unknown to compute attack rates
Table 2: Ebola Attack rates per 10,000 population by county, Gulu district , Uganda, 2000

\begin{tabular}{|l|c|c|c|c|}
\hline County & $\begin{array}{c}\text { Population, } \\
\mathbf{2 0 0 0}\end{array}$ & $\begin{array}{c}\text { Confirmed } \\
\text { cases }\end{array}$ & $\begin{array}{c}\text { Attack } \\
\text { rates }\end{array}$ & $\begin{array}{c}\text { Relative } \\
\text { risk* }\end{array}$ \\
\hline Omoro* & 111,886 & 19 & 1.6 & 1.0 \\
\hline Aswa & 88,450 & 9 & 1.0 & 0.6 \\
\hline Mwoya & 45,350 & 10 & 2.2 & 1.4 \\
\hline Gulu Municipality & 45,768 & 109 & 23.8 & 14.9 \\
\hline Kilak & 105,995 & 32 & 3.0 & 1.9 \\
\hline
\end{tabular}

* Reference county

fold) compared with other rural counties ( Table 2). It once the diagnosis was confirmed it took just 3 weeks took 6 months to contain the outbreak which had in- to contain the outbreak. Community mobilisation and vaded the municipality through slums. involvement contained the outbreak. Altogether 116 cases and 39 deaths were confirmed, including 14 health Examples of successful mobilisation: the critical care workers. Unlike in the Gulu outbreak, the health role of the community

Community mobilisation was a central strategy of the units were established.

national response. The community undertook early de-

tection and swift reporting of suspected cases, enforced Early detection was vital in limiting the Luwero 2011 isolation at household level and maintained working re- outbreak to a single case ${ }^{12}$. This was the third outbreak lationship with the rebels. The community included the since 2000. On the 5th of May, a 13 year old girl was rebels and other stakeholders including opinion leaders admitted to Bombo hospital with a 5 day history of and traditional healers.

fever, diarrhoea and vomiting. She was isolated and a

The vital role of the community was demonstrated blood sample taken. She developed vaginal bleeding when a case escaped from Gulu hospital to her ances- and deteriorated and died the following day. The laboratral home in Masindi district. She belonged to an ex- tory results from the Uganda Virus Research Institute, tended family of 73 members in the district. The local Entebbe confirmed the Sudan Ebola subtype ${ }^{12}$. The community imposed quarantine of these members and results were communicated quickly to the community successfully prevented transmission beyond the extend- on the media and on mobile phones. The outbreak was ed family. Some 25 out of 27 total cases in the district promptly contained with just a single fatality. Twenty were only among the extended family members. In con- four contacts were followed up with community suptrast, only one case occurred in the general Masindi dis- port. This should be the ideal scenario for Ebola contrict population of $314,000^{16}$. tainment. This was a typically a rural ebola outbreak.

The fourth Ebola outbreak ${ }^{17}$ occurred in the district of

The second ebola outbreak in Uganda occurred in Bun- Kibaale. On the 12th July 2012, a 16 year old female dibugyo district in 2007. Although we were prepared from Kikaara village $55 \mathrm{~km}$ west of Kagadi. She was this was another different experience. This was a new opening up forest land with her husband when she fell virus which was isolated 6 months after onset. The iso- sick. She was admitted to Hapuyo Health Centre III lation was carried out at the CDC, Atlanta. However with complaints of fever, diarrhoea and vomiting, and a 
nose bleed just before she died. Nine relatives who par- Nyimbwa Health centre IV on the 20th October 2012, and a priest. One health care worker also died. This was died 3 days later and was buried the following day by typically a rural outbreak during which the community relatives from as far as 70 miles away in Jinja. Contac supported the follow up of 408 contacts. Some 24 cases tracing by the community and members of the distric and 16 deaths occurred. The outbreak was contained in task forces was carried on all who participated at the fusix weeks.

neral. A wife, mother and a sister all died within 2 weeks.

The brother of the inex case bad escaped to Mula Six months later another Ebola outbreak erupted in Lu- the national hospital, but was quickly isolated. The Jin-
wero district and was confirmed early by the Uganda Virus Research Institute. This time the index case was and isolated. Some 119 contacts were followed without a 30 year old motorcycle taxi rider. He was admitted to incident. The epidemic was contained in 6 weeks.

\section{Table 3: Propotion of screened suspected cases revalidated as true cases by the supervisors, Uganda}

\begin{tabular}{|l|c|c|c|c|c|}
\hline District & $\begin{array}{c}\text { Identified by } \\
\text { mobile teams }\end{array}$ & $\begin{array}{c}\text { Revalidated } \\
\text { by } \\
\text { supervisors } \\
\text { as cases }\end{array}$ & $\begin{array}{c}\text { Regarded by } \\
\text { supervisors } \\
\text { as non-cases }\end{array}$ & $\begin{array}{c}\text { Positive } \\
\text { predictive } \\
\text { value } \%\end{array}$ & $95 \% \mathrm{Cl}$ \\
\hline Gulu & $1069^{*}$ & 536 & $533^{*}$ & $50.1 \%$ & $47.1-53.2$ \\
\hline Bundibugyo & 192 & 116 & 76 & $60.4 \%$ & $53.1-67.3$ \\
\hline Luwero & 5 & 1 & 4 & $20.0 \%$ & $-{ }^{* * *}$ \\
\hline
\end{tabular}

*Those with all data and infomation available.

*** numbers few.

Table 4: Laboratory results of suspected ebola cases, Bundibugyo, 2007, Uganda

\begin{tabular}{|l|c|c|}
\hline Laboratory status & Number & Proportion \% \\
\hline & & 21.9 \\
\hline Laboratory positive & 42 & 39.5 \\
\hline Laboratory negative & 76 & 38.5 \\
\hline Laboratory negative but probable & 74 & 100 \\
\hline Total tested & 192 & 60.4 \\
\hline $\begin{array}{l}\text { Total lab positive and probable combined } \\
(42+76) / 192\end{array}$ & 116 & \\
\hline
\end{tabular}

\section{Discussion}

in the camps and also in town slums. As a result, attack In this paper we describe our experience with several rates increased steeply in town suburbs of Gulu (Taebola outbreaks in Uganda.

ble1,2). These outcomes depend on the greater mobilLessons to learn from these scenarios are that it was ity of the people and the differences between rural and easier to stop the rural based epidemics. However in urban. While the rural people have a communal spirit, the case of Gulu the outbreak had become urbanised social networks, are self-reliant and are easy to mobi- lise, the urban slum dwellers are individualistic, luck so- cal challenges which affected timely detection and isocial support, and are money dependant and difficult lation of cases. Some of these challenges are associated to mobilise in their overcrowded neighbourhoods. For with some weaknesses in the application of the clinical instance community mobilisation was quick in Masindi syndromic based diagnosis. The clustering of deaths and in response to an ebola patient who had escaped to the bleeding manifestations and the death of health care district from Gulu. The community imposed isolation workers is suspicious. However, there are many condiof all 73 members of the index extended family. Of the tions that mimic Ebola in Uganda and include illnesses family. Only one case came from the general population

Role of early detection and action atypical cases presented without fever or bleeding. Fever was absent in $15 \%$ of cases while bleeding tendencies were observed only in $30-53 \%$ of admissions in Gulu ${ }^{18}$. Bleeding manifestation was also rare in the fection and late action in the districts of Gulu district cases identified by the community surveillance were re(6 weeks); Bundibugyo (6 months); Kibaale (6 weeks). validated as true cases. Only half of the suspected and Most $(75 \%)$ of the delays were at community level. probable Ebola cases tested yielded positive laboratory Once the diagnosis was made, it took on average 5- 17 results ${ }^{20}$ (Table 3). This low positive predictive value for days to contain the outbreak, except for the Gulu out- the case definition and the laboratory tests is a major break. It took 66 days post confirmation to register weakness affecting early diagnosis critical in initiating the last case in Gulu. The Luwero outbreak of 2011 the national response.This is frustrating to the patients was contained during the first week. The critical role and the community. Laboratory tests and results helped of early diagnosis and action was vital in containment. in the confirmation of cases and the management of admission to isolation units and also the management of discharges. The sensitivity and the specificity of the

Challenges in early diagnosis and detection Besides the slum environment there were some techni-
Table 5: Timeline and level of delays in outbreak confirmation of cases, Uganda, 2000- 2012

\begin{tabular}{|c|c|c|c|c|c|c|}
\hline District & Gulu, 2000 & & Bundibugyo, & 2007 & Luwero, 20 & \\
\hline Level & Date & $\begin{array}{l}\text { Days } \\
\text { since } \\
\text { onse } \\
t\end{array}$ & Date & $\begin{array}{l}\text { Days } \\
\text { since } \\
\text { onse } \\
\mathrm{t}\end{array}$ & Date & $\begin{array}{l}\text { Days } \\
\text { since } \\
\text { onse } \\
t \\
\end{array}$ \\
\hline $\begin{array}{l}\text { Onset of strange disease } \\
\text { in community }\end{array}$ & $\begin{array}{l}19 / 09 / 200 \\
0\end{array}$ & 0 & $02 / 08 / 2007$ & 0 & $\begin{array}{l}01 / 05 / 201 \\
1\end{array}$ & 0 \\
\hline Report to Ministry Health & $9 / 10 / 2000$ & 20 & $\begin{array}{l}27 / 09 / / 200 \\
7\end{array}$ & 56 & $\begin{array}{l}06 / 05 / 201 \\
1\end{array}$ & 6 \\
\hline $\begin{array}{l}\text { Investigation: Blood } \\
\text { sampled }\end{array}$ & $\begin{array}{l}12 / 10 / 200 \\
0\end{array}$ & 24 & 29/09/2007 & 59 & $\begin{array}{l}06 / 05 / 201 \\
1\end{array}$ & 6 \\
\hline Blood confirmation Ebola & $\begin{array}{l}14 / 10 / 200 \\
0\end{array}$ & 26 & 28/11/2007 & 117 & $\begin{array}{l}09 / 05 / 201 \\
1\end{array}$ & 9 \\
\hline Declaration national action & $\begin{array}{l}15 / 10 / 200 \\
0\end{array}$ & 27 & 29/11/2007 & 118 & $\begin{array}{l}\text { 09/05/201 } \\
1\end{array}$ & 9 \\
\hline Last Case & $\begin{array}{l}14 / 01 / 200 \\
1\end{array}$ & 117 & $08 / 01 / 2008$ & 159 & $\begin{array}{l}\text { 06/05/201 } \\
1\end{array}$ & 0 \\
\hline $\begin{array}{l}\text { Total days epidemic } \\
\text { lasted }\end{array}$ & & 117 & & 159 & & 6 \\
\hline $\begin{array}{l}\text { From laboratory } \\
\text { confirmation } \\
\text { to last case }\end{array}$ & & 91 & & 42 & & -6 \\
\hline
\end{tabular}

** Timelines approximate 


\section{Isolation and case management}

Isolation and care plays a critical part in outbreak management. We demonstrated in the Gulu outbreak that isolation and care actually reduced mortality ${ }^{18}$. When the health care workers become more confident and motivated performance and patient survival improved. There was reduction in case fatality from $100 \%$ at the beginning of the outbreak to less than $50 \%$ as quality treatment was instituted over time ( Fig 5). Hence care and survival and not just quarantine be emphasized.

Inadequate human resource was a major challenge in the operations of the isolation wards. Isolation wards are labour intensive; they need adequate, motivated and well rewarded workers.

\section{Similarities with the West Africa outbreak}

The ebola outbreak in West Africa is very similar to the outbreak in Gulu. Both occurred in slum conditions in low resource countries. The Gulu outbreak started in a remote rural village near Southern Sudan, and entered the slums of Gulu municipality. It also entered the overcrowded slum like internally displaced persons (IDP) camps. In Gulu confirmation was done 3 weeks after onset. In West Africa the outbreak started at a remote common border of three countries but took nearly 6 months to confirm ${ }^{19,21}$. Guinea, Sierra Leone and Liberia were severely affected. The clinical and technical challenges were similar to the Gulu experience. There was also a problem with laboratory outcomes. Only half of the suspected and probable cases yielded positive laboratory results ${ }^{18-21}$. At its peak, some 150 new cases were reported daily ${ }^{22}$. By February 2015 some 22,000 cases with 8800 cases had been reported and $10 \%$ were health care personnel ${ }^{23}$. This unexpected burden of disease and death overwhelmed the health care system. Gaps in isolation procedures were reported in both outbreaks ${ }^{18,19}$.In Gulu there was failure to implement barrier nursing as $64 \%$ of the 31 health care workers got infected after the establishment of the isolation units. In Gulu several of these infections occurred inadvertently in general wards. Some also occurred among support staff including ambulance drivers. It is reported also that 19 out 25 staff working in the Ebola isolation ward in Kenema hospital in Sierra Leone also contracted the infection ${ }^{19}$. An assessment of the causes of this breach in barrier nursing needs further investigation.

\section{Conclusion}

The experiences of Uganda are relevant but should be ut in their true perspective.

Africa potentially remains the epicenter of the burden created by Ebola virus disease (EVD). Practical steps must be taken at country level particularly in critical areas.

First there is a need to strengthen leadership at community level for contact tracing and the early identification and isolation of cases. This was the backbone of the management of infection in the affected areas in the Uganda context. This was applied in the rural and later in the slum settlements in the Gulu municipality. Second, the need to strengthen laboratory capacity for early detection of the infection is critical. Third, focusing on supportive treatment and survival not just quarantine as such intervention reduced case mortality, isolated case and increased public trust. Fourth, the need to eliminate the gaps in barrier nursing by institutionalizing infection control policy and plans in health facilities for ALL health workers and ALL their working environments. Fifth, the need to develop a human resource policy and plan that attracts rewards and retains workers. In order to support these critical areas there is a need to strengthen health care systems so that they can readily respond to the demands of future outbreaks.

There is need to strengthen international collaboration and partnerships to support the building of comprehensive health systems for surveillance and care. Regional teams and Centers of Excellence will need to be developed to support rapid response and provide timely emergency stocks, expertise and technical support. The experience in West Africa demonstrates that the outbreak if note detected early can paralyze socioeconomic activities and impact on development and security. The best hope for low resource countries at least for now is early detection and action.

\section{Acknowledgements}

We acknowledge the contributions from all the organizations, institutions, professionals, health care workers, political and civic leaders and local communities and the support from the international agencies and partners. The following were key local contributors:

Ministry of Health, Uganda; Office of the Prime Minister, Uganda; District Councils for Gulu, Masindi, Mbarara, Bundibugyo, Luwero; Gulu, Lacor and Mbarara hospitals; Bundibugyo hospital; Mulago hospital. We also give special thanks to these international organizations and Partners who were major contributors:
DFID, SIDA, DANIDA, Italian Cooperation, Chinese Red Cross, and AMREF

References

1. Okware, S.I., et al., An outbreak of Ebola in Uganda. Tropical medicine \& international health: TM \& IH, 2002. 7(12): p. 1068-75.

2. Wamala, J.F., et al., Ebola hemorrhagic fever associated with novel virus strain, Uganda, 2007-2008. Emerging infectious diseases, 2010. 16(7): p. 1087-92.

3. WHO, Ebola haemorhagic fever in Zaire,1976. Bull World Health Organ 1978, 1978. 56: p. 271-93

4. Heymann, D.L., et al., Ebola hemorrhagic fever: Tandala, Zaire, 1977-1978. The Journal of infectious diseases, 1980. 142(3): p. 372-6.

5. Dowell, S.F., et al., Transmission of Ebola hemorrhagic fever: a study of risk factors in family members, Kikwit, Democratic Republic of the Congo, 1995. Commission de Lutte contre les Epidemies a Kikwit. The Journal of infectious diseases, 1999. 179 Suppl 1: p. S8791.

6. Khan, A.S., et al., The reemergence of Ebola hemorrhagic fever, Democratic Republic of the Congo, 1995. Commission de Lutte contre les Epidemies a Kikwit. The Journal of infectious diseases, 1999. 179 Suppl 1: p. S76-86.

. Georges, A.J., et al., Ebola hemorrhagic fever outbreaks in Gabon, 1994-1997: epidemiologic and health control issues. The Journal of infectious diseases, 1999. 179 Suppl 1: p. S65-75.

8. Lamunu, M., et al., Containing a haemorrhagic fever epidemic: the Ebola experience in Uganda (October 2000-January 2001). International journal of infectious diseases: IJID : official publication of the International Society for Infectious Diseases, 2004. 8(1): p. 27-37. 9. Sanchez, A., Filoviridae: Marburg and Ebola viruses., in Fields virology., D. Knipe and P. Howley, Editors. 2007, Lippincott Williams \& Wilkins: Philadelphia. p. $1409-48$

10. Bowen, E.T., et al., A comparative study of strain of Ebola virus isolated from southern Sudan and northern Zaire in 1976. Journal of medical virology, 1980. 6(2): p. 129-38.

11. Geisbert, T.W., et al., Pathogenesis of Ebola hemorrhagic fever in cynomolgus macaques: evidence that dendritic cells are early and sustained targets of infecion. The American journal of pathology, 2003. 163(6): p. 2347-70.

12. Shoemaker, T., et al., Reemerging Sudan Ebola virus disease in Uganda, 2011. Emerging infectious diseases, 2012. 18(9): p. 1480-3.

13. $\mathrm{MOH}$, Report of an investgation of suspected Ebola infection in animals and humans in Mpigi and Wakiso districts, Uganda, January 2008, K. Winyi, Editor 2008, $\mathrm{MOH}$.

14. UNICEF, Humantarian action report 2007, 2007 , UNICEF Uganda: Uganda.

15. WHO, Health and mortality survey among internally displaced persons in Gulu, Kitgum and Pader districts, northern Uganda, 2005, World Health Organization (WHO): Geneva. p. 65.

16. Borchert, M., et al., Ebola haemorrhagic fever outbreak in Masindi District, Uganda: outbreak description and lessons learned. BMC Infect Dis, 2011. 11: p. 357.

17. $\mathrm{MOH}$, Ministry of Health Epidemiogical Report of the Kibaale district Ebola Outbreak, Uganda, 18th September , 2012, L. Lukwago, Editor 2012, MOH: Kampala.

18. Okware, S., Three ebola outbreaks in Uganda, 2000-2011, in Uib BORA2015.

19. Schieffelin, J.S., et al., Clinical illness and outcomes in patients with Ebola in Sierra Leone. N Engl J Med, 2014. 371(22): p. 2092-100.

20. Okware, S., Three ebola outbreaks in Uganda 20002011 , in uib2015, bergen.

21. WHO, Ebola Outbreak in West Africa | Ebola Hemorrhagic ... 2015

22. Kreiter, M., Ebola Outbreak: CDC Estimates As Many As 500,000 Ebola Cases By End Of January, 2014: International Business Times.

23. WHO, Ebola Outbreak in West Africa - Case Counts - Centers ... 2014 